\title{
EFEKTIVITAS EKSTRAK ETANOL DAUN KENIKIR (Cosmos caudatus Kunth) TERHADAP PENYEMBUHAN LUKA SAYAT PADA MENCIT (Mus musculus L.)
}

\author{
Laila Novita Sari $^{1 *}$, M. Kanedi ${ }^{2}$ Yulianty $^{3}$, Eti Ernawiati ${ }^{4}$ \\ 1, 2,3,4 Jurusan Biologi, Fakultas MIPA, Universitas Lampung, Indonesia \\ *Email: lailanovita@gmail.com
}

Received: July $18^{\text {th }}, 2019$. Accepted: September $29^{\text {th }}, 2019$. Published: December $29^{\text {th }}, 2019$

\begin{abstract}
The purpose of this study is to know the ethanol extract of the leaves of kenikir (Cosmos caudatus Kunth) On the healing of wounds in mice (Mus musculus L.) with different concentrations of 10\%, 15\%, 20\%, 25\%. This study used a completely randomized design (CRD), with 6 treatments and 4 repetitions. Consisting of $K+$ with povidone iodine, $K$ - with Aquades, $P 1$ with ethanol extract of $10 \%$ kenikir leaves, P2 15\%, P3 20\% and P4 25\%. The treatment is carried out in the morning and evening for 14 days. The results of the analysis used were homogeneity test, ANOVA and BNT further test at the level of 5\%. The results of this study indicate that the ethanol extract of kenikir leaves can accelerate healing in incised wounds which can be seen from the description of the results of histopathological observation of mice skin.
\end{abstract}

Keywords: Cosmos Caudatus Kunth; Mus Musculus L; Povidone Iodine; Wound

\begin{abstract}
ABSTRAK
Tujuan dari penelitian ini yaitu mengetahui ekstak etanol daun kenikir (Cosmos caudatus Kunth) terhadap penyembuhan luka sayat pada mencit (Mus musculus L.) dengan konsentrasi yang berbeda yaitu 10\%, 15\%, 20\%, 25\%. Penelitian ini menggunakan Rancangan Acak Lengkap (RAL), dengan 6 perlakuan dan 4 kali pengulangan. Terdiri dari $\mathrm{K}+$ dengan povidone iodine, $\mathrm{K}$ - dengan Aquades, $\mathrm{P} 1$ dengan ekstrak etanol daun kenikir 10\%, P2 15\%, P3 20\% dan P4 25\%. Pemberian perlakuan dilakukan pada pagi dan sore hari selama 14 hari. Hasil analisis yang digunakan yaitu uji homogenitas, ANOVA dan uji lanjut BNT pada taraf 5\%. Hasil penelitian ini menunjukkan bahwa ekstrak etanol daun kenikir dapat mempercepat penyembuhan pada luka sayat yang dapat dilihat dari gambaran hasil pengamatan histopatologi kulit mencit.
\end{abstract}

Kata kunci: Cosmos Caudatus Kunth; Mus Musculus L; Povidone Iodine; Luka Sayat.

\section{PENDAHULUAN}

Kulit sebagai pelindung organ dari gangguan luar seperti terkena air, sinar matahari, suhu, dan rangsangan. Ketika kulit mengalami trauma maka fungsi kulit akan terganggu (Kalangi 2013). Kulit yang luka karena rusaknya jaringan atau struktur anatomi kulit yang disebabkan kontak fisik oleh benda tajam atau tumpul, hasil tindakan medis, gigitan hewan, sumber panas seperti tersengat listrik, ledakan, zat kimia maupun perubahan kondisi fisiologis 
(Rahmatia 2016). Luka sayat (vulnus scissum), adapun luka yang ditandai dengan tepi luka berupa garis lurus dan beraturan (Orsted H, Keast D, Kuhnke J, Armstrong P, Attrell E, Beaumier M 2010).

Penyembuhan luka pada tubuh manusia dapat berlangsung dengan sendirinya tetapi memerlukan waktu yang cukup lama, biasanya berkisar dari 5 hingga 10 hari (Elnar dan Ailey 2016) sehingga indikasi terjadinya infeksi yang diakibatkan bakteri, jamur dan parasit akan semakin tinggi Obat luka untuk mempercepat proses penyembuhan pada luka. Karena Obat terbagi menjadi dua macam yaitu obat-obatan kimia dan herbal, penggunaan obat yang berasal dari tumbuhan atau herbal sudah lama menjadi bagian dari perawatan kesehatan turun-temurun manusia. Maka untuk Obat luka biasanya banyak mengandung antiseptik untuk mencegah infeksi, antiseptik yang sering digunakan betadine (povidone iodine) karena aktivitas bakterisidal dan toksisitasnya yang rendah serta harganya yang cukup terjangkau, namun penggunaan obat tersebut dapat menimbukan iododerma atau alergi (Rahmawati 2014; Rahim, Aria, dan Aji 2015). Oleh karena itu diperlukan pengobatan alternatif untuk penyembuhan luka (Massé, Falanga, dan Zhou 2008)

Tanaman Kenikir (Cosmos caudatus Kunth) banyak tumbuh di Indonesia, Selain dimanfaatkan sebagai sayuran dan lalapan manfaat lain dari kenikir juga dapat penambah nafsu makan, lemah lambung, menguatkan tulang, dan sebagai pengusir serangga. Antioksdian sendiri dapat mencegah kerusakan jaringan yang merangsang proses penyembuhan luka seperti flavonid, alkaloid, saponin dan tanin (Homology dkk. 2007). Kandungan senyawa flavonoid, saponin dan tanin tersebut diduga dapat mempercepat penyembuhan pada luka. Adapun penelitian sebelumnya oleh yang menunjukan pada daun kenikir memiliki kandungan kimia yang mempunyai sifat antioksidan dan antibakteri (Afianti dan Murrukmihadi 2015; Izza dkk. 2016). Namun ekstrak daun kenikir pada penelitian sebelumnya belum diteliti luka pada mencit. Berdasarkan pernyataan di atas, maka dilakukan penelitian tentang uji efek ekstrak daun kenikir (Cosmos caudatus Kunth.) terhadap penyembuhan luka sayat pada punggung mencit (Mus musculus L.).

\section{METODE}

Penelitian ini dilakukan pada bulan Februari sampai Maret 2019 di Laboratorium Zoologi Jurusan Biologi FMIPA Unila dan Laboratorium Patologi Balai Besar Penyidikan dan Pengujian Veteriner Regional III Provinsi Lampung. 
Peralatan yang digunakan pada penelitian ini adalah blender,oven, kertas saring, corong buchner, dan rotary evaporator, kandang mencit, wadah pakan, dan wadah minum. Neraca analitik, Gelas ukur dan pipet tetes, gunting, pisau bedah, jangka sorong, kapas, sarung tangan dan masker. Bahan yang digunakan dalam penelitian ini adalah daun kenikir, povidone iodine, aquades, etanol 96\% lidokain dan klorofom. Penelitian ini menggunakan Rancangan Acak Lengkap (RAL) dengan 6 perlakuan pada mencit sebagai hewan uji, dimana setiap perlakuan dilakukan pengulangan sebanyak 4 kali

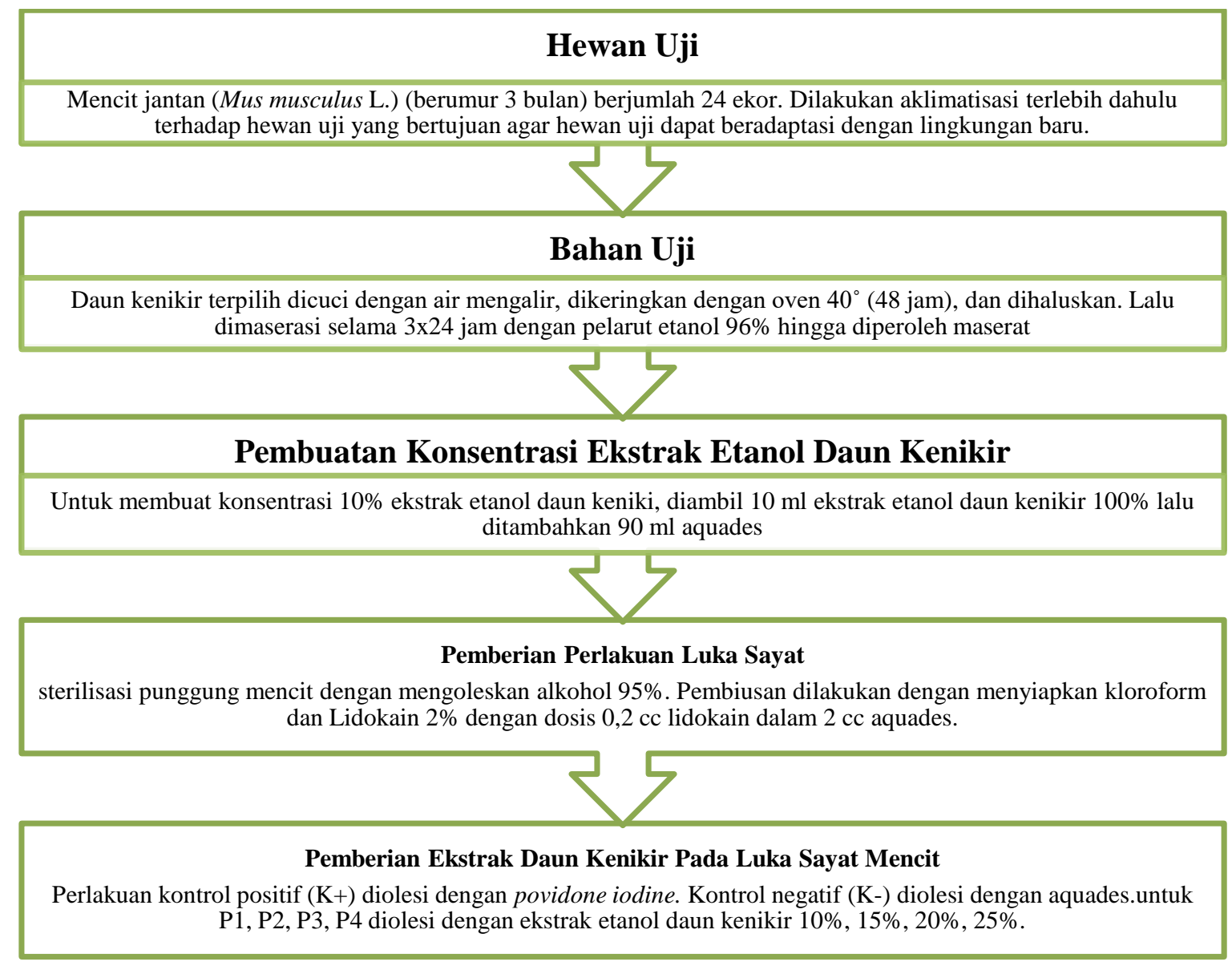

Gambar 1. Rancangan Acak Lengkap (RAL)

Pembuatan Preparat Histopatologi Dua ekor mencit dari masing-masing kelompok perlakuan dibuat preparat histopatologi, sehingga didapatkan 12 sampel kulit mencit untuk dilakukan pembuatan preparat histopatologi. Pembuatan preparat histopatologi dilakukan di Laboratorium Patologi Balai Besar Penyidikan dan Pengujian Veteriner Regional III Provinsi Lampung. Parameter yang diamati pada penelitian ini adalah pengamatan secara makroskopis yang meliputi waktu penyembuhan, panjang luka, kemerahan pada luka, pembentukan krusta 
serta produksi pus. Mikroskopis yang meliputi pembentukan epitelisasi, pembentukan pembuluh darah dan sel inflamasi. Analisis Datan yang diperoleh diuji homogenitasnya, kemudian dianalisis dengan metode analisis ragam dengan menggunakan SPPS 16.

\section{HASIL DAN PEMBAHASAN}

Pengamatan ini dilakukan untuk melihat perkembangan penutupan luka sayat mencit pada setiap perlakuan dengan konsentrasi yang berbeda. Berikut merupakan data rerata perkembangan penutupan luka pada masing-masing kelompok percobaan yang dapat dilihat pada Tabel 1.

Tabel 1. Rerata Persentase Panjang Penutupan Luka Pada Setiap Perlakuan

\begin{tabular}{|c|c|}
\hline Perlakuan & $\begin{array}{c}\text { Perkembangan Ukauran Penutupan Luka }(\mathrm{cm}) \\
\text { Selama } 10 \text { hari }(\text { Mean } \pm \text { SEM) }\end{array}$ \\
\hline $\mathrm{K}(+)$ & $83,07 \pm 9,78$ \\
\hline $\mathrm{K}(-)$ & $78,72 \pm 12,38$ \\
\hline $\mathrm{P} 1$ & $89,49 \pm 10,52$ \\
\hline $\mathrm{P} 2$ & $100,00 \pm 0,00$ \\
\hline P3 & $91,42 \pm 8,57$ \\
\hline $\mathrm{P} 4$ & $83,7 \pm 6,42$ \\
\hline \multicolumn{2}{|c|}{$\begin{array}{r}\text { Keterangan: } \mathrm{K}(+)=\text { Kontrol positif, luka diolesi povidone iodine } \\
\mathrm{K}(-)=\text { Kontrol negatif, luka diolesi dengan aquades } \\
\mathrm{P} 1=\text { Perlakuan 1, luka diolesi ekstrak etanol daun kenikir } 10 \% \\
\mathrm{P} 2=\text { Perlakuan 2, luka diolesi ekstrak etanol daun kenikir } 15 \% \\
\mathrm{P} 3=\text { Perlakuan 3, luka diolesi ekstrak etanol daun kenikir } 20 \% \\
\text { P4 = Perlakuan 4, luka diolesi ekstrak etanol daun kenikir } 25 \% .\end{array}$} \\
\hline Berdasarkan data & erlakuan kedua (P2) yang diberikan ekstrak etanol daun \\
\hline \multicolumn{2}{|c|}{ kenikir $15 \%$ memiliki persentase paling tinggi yakni $100 \%$. Selanjutnya pada perlakuan ketiga } \\
\hline \multirow{2}{*}{\multicolumn{2}{|c|}{$\begin{array}{l}\text { (P3) yang diberikan ekstrak etanol daun kenikir } 20 \% \text { memiliki persentase perkembangan } \\
\text { penurunan panjang luka sebesar } 91,42 \% \text {. Perlakuan pertama (P1) yang diberikan ekstrak etanol }\end{array}$}} \\
\hline & \\
\hline \multicolumn{2}{|c|}{ daun kenikir $10 \%$ memiliki persentase perkembangan penurunan panjang luka sebesar $89,49 \%$. } \\
\hline \multicolumn{2}{|c|}{$\begin{array}{l}\text { Untuk perlakuan keempat (P4) yang diberikan ekstrak etanol daun kenikir } 25 \% \text { memiliki } \\
\text { persentase perkembangan penurunan panjang luka sebesar } 83,78 \% \text {. Perlakuan kontrol positif }\end{array}$} \\
\hline \multicolumn{2}{|c|}{$(\mathrm{K}+)$ yang diberikan povidone iodine memiliki persentase perkembangan penurunan panjang } \\
\hline luka sebesar $83,07 \%$ & kontrol negatif $(\mathrm{K}-)$ yang hanya diberikan aquades \\
\hline memiliki persentase pe & nurunan panjang luka pada hari terakhir sebesar 78,72 \\
\hline
\end{tabular}


Kelompok perlakuan dengan menggunakan ekstrak daun kenikir memiliki rerata panjang penutupan luka yang lebih baik dibandingkan dengan kontrol negatif. Hal tersebut dikarenakan adanya senyawa metabolit aktif saponin yang terkandung dalam ekstrak etanol daun kenikir yang dapat membantu proses penyembuhan pada lukaberdasarkan hasil analisis ragam tidak memiliki perbedaan nyata.

Pengamatan waktu penyembuhan dilakukan untuk melihat perbedaan waktu penyembuhan luka pada setiap perlakuan. Berikut merupakan data rerata waktu penyembuhan luka sayat pada mencit.

Tabel 2. Rerata Waktu Penutupan Luka Sayat Pada Mencit Selama 10 Hari

\begin{tabular}{cc}
\hline Perlakuan & $\begin{array}{c}\text { Rerata Waktu Penutupan Luka Sayat Pada Mencit Selama 10 } \\
\text { hari (Mean } \pm \text { SEM) }\end{array}$ \\
\hline $\mathrm{K}(+)$ & $10,25 \pm 1,70$ \\
$\mathrm{~K}(-)$ & $8,75 \pm 1,93$ \\
P1 & $8,00 \pm 1,64$ \\
P2 & $5,50 \pm 0,65$ \\
P3 & $7,75 \pm 1,55$ \\
P4 & $9,75 \pm 2,14$ \\
\hline
\end{tabular}

Keterangan: $\mathrm{K}(+)=$ Kontrol positif, luka diolesi povidone iodine

$\mathrm{K}(-)=$ Kontrol negatif, luka diolesi dengan aquades

$\mathrm{P} 1=$ Perlakuan 1, luka diolesi ekstrak etanol daun kenikir $10 \%$

P2 = Perlakuan 2, luka diolesi ekstrak etanol daun kenikir 15\%

P3 = Perlakuan 3, luka diolesi ekstrak etanol daun kenikir 20\%

P4 = Perlakuan 4, luka diolesi ekstrak etanol daun kenikir 25\%

Hasil penelitian yang didapatkan menunjukkan bahwa waktu penutupan luka paling cepat terdapat pada P2 dengan rerata waktu penutupan luka 5,5 hari. Kemudian P3 dengan rerata waktu penutupan luka 7,75 hari, berikutnya P1 dengan rerata waktu penyembuhan selama 8 hari dan $\mathrm{P} 4$ dengan rerata waktu penyembuhan 9,75 hari. Untuk perlakuan $\mathrm{K}(+)$ atau kontrol positif menunjukkan rerata penyembuhan selama 10,25 hari dan $\mathrm{K}(-)$ dengan rerata waktu penutupan luka selama 8,75 hari. Hasil analisis ragam menunjukkan bahwa waktu penyembuhan luka dengan konsentrasi yang berbeda tidak adanya pengaruh yang nyata antar perlakuan $(\mathrm{p}>0,05)$.

Berdasarkan hasil gambaran histopatologi kulit mencit maka dapat dibuat rerata skoring histologi kulit yang dapat dilihat pada tabel dibawah ini. 
Tabel 3. Data Rerata Skor Histopatologi Luka Sayat Pada Mencit

\begin{tabular}{|c|c|c|c|c|c|}
\hline \multirow[b]{2}{*}{ Perlakuan } & \multicolumn{3}{|c|}{ Skor } & \multirow[b]{2}{*}{ Total skor } & \multirow[b]{2}{*}{ Rata-rata } \\
\hline & $\mathbf{A}$ & B & C & & \\
\hline $\mathbf{K}+$ & 2 & 1 & 1 & 4 & 1,33 \\
\hline $\mathbf{K}-$ & 3 & 1 & 1 & 5 & 1,67 \\
\hline P1 & 3 & 1 & 1 & 5 & 1,67 \\
\hline P2 & 3 & 3 & 2 & 8 & 2,67 \\
\hline P3 & 3 & 1 & 2 & 6 & 2 \\
\hline P4 & 2 & 1 & 1 & 4 & 1,33 \\
\hline
\end{tabular}

Keterangan: a Epitelisasi ; b. Pembuluh Darah ; c. Sel Inflamasi.

$\mathrm{K}(+)=$ Kontrol positif, luka diolesi povidone iodine

$\mathrm{K}(-)=$ Kontrol negatif, luka diolesi dengan aquades

P1 = Perlakuan 1, luka diolesi ekstrak etanol daun kenikir 10\%

$\mathrm{P} 2$ = Perlakuan 2, luka diolesi ekstrak etanol daun kenikir 15\%

P3 = Perlakuan 3, luka diolesi ekstrak etanol daun kenikir 20\%

P4 = Perlakuan 4, luka diolesi ekstrak etanol daun kenikir 25\%

Berdasarkan parameter dan deskripsi pengamatan histopatologi luka, tabel hasil rerata skor histopatologi luka sayat terlihat rerata yang paling tinggi didapatkan oleh P2 dengan rerata skor 2,67 kemudian P3 dengan rerata skor 2, selanjutnya P1 dan K- dengan rerata skor 1,67. $\mathrm{K}+$ dan P4 dengan rerata skor 1,33. Rerata waktu penyembuhan luka sayat pada perlakuan kontrol positif yang diberikan povidone iodine lebih lambat dibandingkan dengan perlakuan negatif atau yang hanya diolesi dengan aquasdes. Hal ini disebabkan povidone-iodine memiliki efek pada eksotoksin dan enzim bakteri, yang dapat menyebabkan tambahan kerusakan pada jaringan dan memperpanjang proses inflamasi (Teixeira dkk. 2018).

Kelompok perlakuan dengan ekstrak etanol daun kenikir rerata waktu penyembuhan luka lebih cepat dibandingkan dengan kontrol negatif yang diolesi dengan aquades karena daun kenikir memiliki senyawa aktif atau senyawa metabolit sekunder yang dapat membantu penyembuhan pada luka. Berdasarkan hasil uji analisi ragam menunjukan tidak adanya pengaruh yang nyata pada setiap kelompok perlakuan. 


\section{Pengamatan kemerahan pada tepi luka, Pembentukan Krusta dan Pus (alergi)}
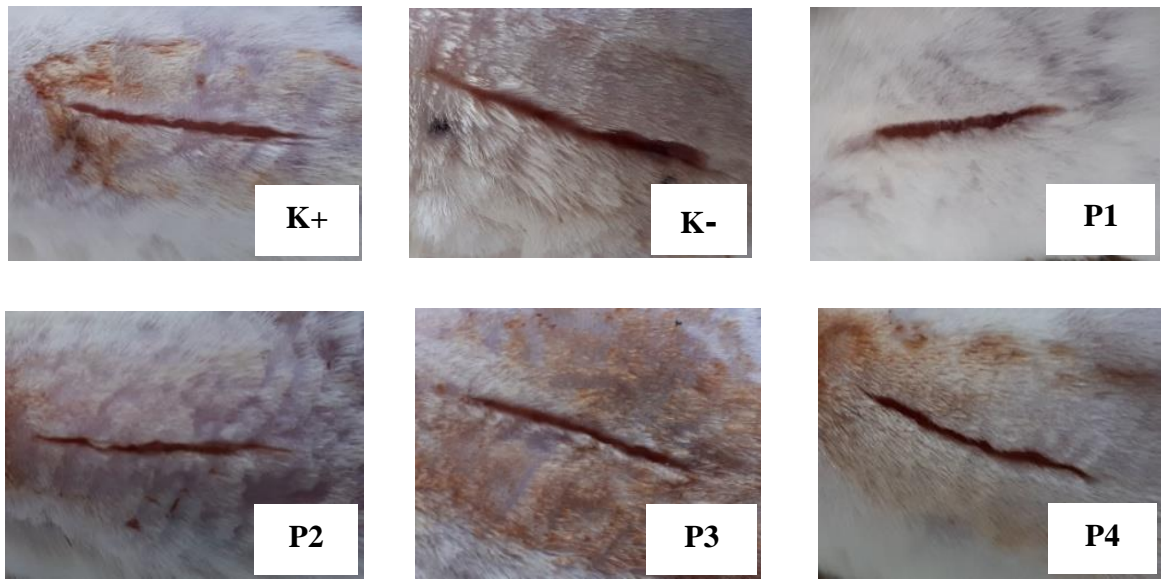

Gambar 2. Hasil Pengamatan Setelah 24 Jam Setelah Pemberian Perlakuan

Hasil pengamatan setelah 24 jam didapat, keenam kelompok perlakuan menunjukan adanya kemerahan pada luka, luka terlihat mulai mengering tetapi belum terlihat adanya krusta (keropeng). Hari ke-4 Terdapat krusta pada keenam perlakuan, untuk perlakuan yang diberikan ekstrak etanol daun kenikir 20\% dan 25\% (e dan f) sudah nampak krusta yang mengering dan terkelupas. Pada hari ke-6 luka pada perlakuan P2 menunjukan kemerahan yang paling sedikit dan luka mulai menutup. Hari ke-12 Krusta sudah tidak nampak pada setiap kelompok perlakuan.
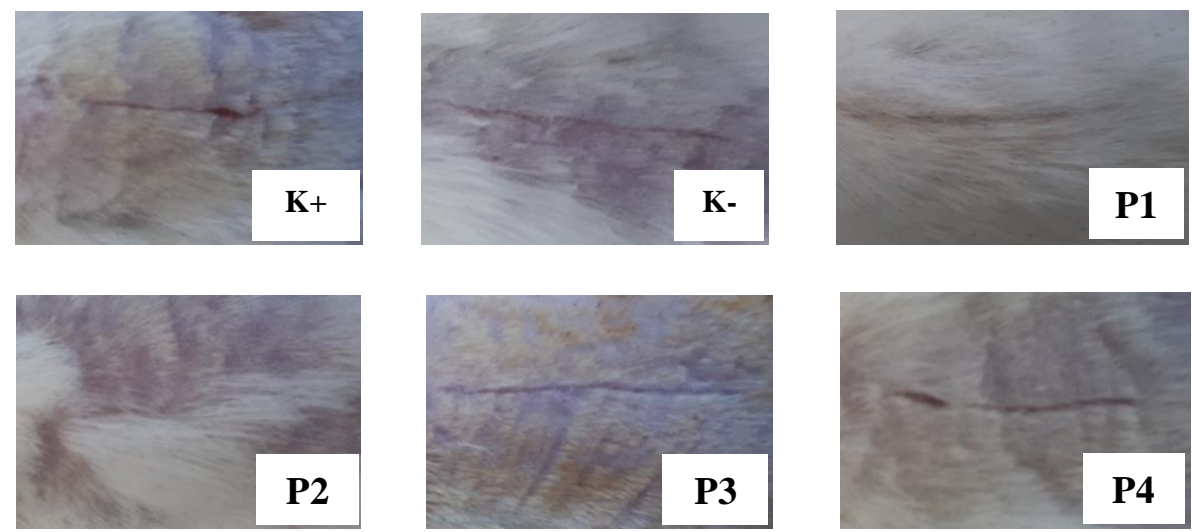

Gambar 3. Hasil pengamatan hari ke-14

Hari ke-14 kemerahan pada luka masih sedikit terdapat pada kelompok perlakuan yang diberikan povidone iodine (a) dan pada kelompok perlakuan diberikan ekstrak etanol daun kenikir $25 \%$ (f). Tidak adanya produksi pus (nanah) selama 14 pengamatan. 


\section{Desember 2019}

\section{Pengamatan Secara Mikroskopis}
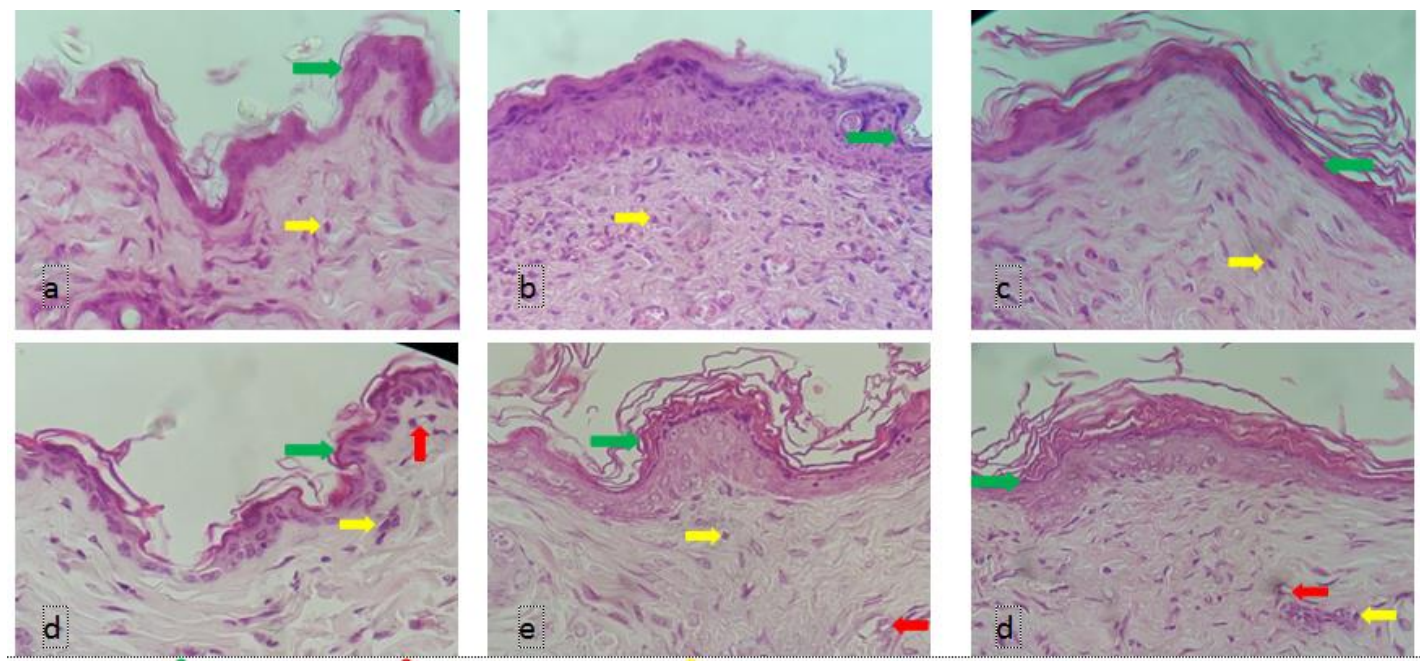

Keterangan : $\Rightarrow$ = Epitalisasi $\quad \Rightarrow$ = Pembuluh Darah $\quad \Rightarrow$ = Sel Inflamasi

Gambar 4. Gambaran histologi melintang kulit (a) luka sayat yang diberi povidone iodine $\mathrm{K}+$, (b) luka sayat yang diberi aquades $\mathrm{K}-$, (c) luka sayat yang diberi ekstrak etanol daun kenikir 10\%, (d) luka sayat yang diberi ekstrak etanol daun kenikir $15 \%$, (e) luka sayat yang diberi ekstrak etanol daun kenikir 20\%, dan (f) luka sayat yang diberi ekstrak etanol daun kenikir $25 \%$.

Hasil gambaran histopatologi kulit mencit yang diamati secara deskriptif terlihat histopatologi yang berbeda-beda. Berdasarkan gambaran histopatologi kulit mencit yang diolesi dengan aquades terlihat lebih baik dibandingkan dengan kontrol positif yang diolesi dengan povidone iodine terlihat epitelisasi yang masih sedikit dan belum adanya pembuluh darah yang terlihat per lapang pandang mikroskop.

Gambaran histopatologi kulit mencit yang diberikan ekstrak etanol daun kenikir terlihat perlakuan yang paling baik adalah P2 yaitu yang diberikan ekstrak etanol daun kenikir 15\% yang terlihat epitelisasi normal, sel inflamasi kurang dari 15 sel dan terdapat lebih dari 2 pembuluh darah. Hal tersebut dikarenakan adanya senyawa metabolit aktif flavonoid, tanin dan saponin yang terkandung dalam ekstrak etanol daun kenikir yang dapat membantu proses penyembuhan pada luka.

Senyawa metabolit sekunder yang terdapat pada daun kenikir adalah flavonoid yang bersifat anti-inflamasi. Flavonoid mengandung fraksi yang dapat mempersingkat periode peradangan dan memberikan kontribusi perlawanan terhadap infeksi yang disebabkan oleh mikroorganisme (Lodhi dan Singhai 2013). Mekanisme kerja dalam melawan mikroorganisme yakni flavonoid akan membentuk senyawa kompleks dengan protein ekstraseluler dan terlarut sehingga dapat merusak membran sel bakteri dan diikuti dengan keluarnya senyawa 
intraseluler sehingga sel tidak dapat diperbaiki kembali (Bontjura, Waworuntu, dan Siagian 2015)

Senyawa metabolit lainnya yang terkandung dalam daun kenikir adalah tanin. Menurut (Kusumawardhani, Aliefia Ditha. Kalsum, Umi. Rini 2015) astringen pada kandungan senyawa tanin dapat menghentikan pendarahan pada luka. Selanjutnya, senyawa metabolit sekunder lainnya yang terkandung di dalam daun kenikir adalah saponin. Kandungan saponin mampu mempercepat proses re-epitelisasi pada jaringan epidermis dan infiltrasi sel-sel radang pada daerah luka (Napanggala dan Apriliana, t.t.) Saponin disebut growth factor karena mekanisme kerja saponin dapat merangsang pembentukan sel-sel baru dengan penggandaan dan pertumbuhan sel endotel pembuluh darah, sel otot polos pembuluh darah dan fibroblas, sehingga menimbulkan pertumbuhan seluler yang akhirnya dapat memperbaiki dinding pembuluh darah yang rusak (Murti dkk. 2017)

Hasil pengamatan mikroskopis pada penelitian ini bahwa ekstrak etanol daun kenikir $15 \%$ (P2) menunjukan hasil yang paling baik diantara perlakuan yang lain. Hal ini selaras dengan penelitian (Rosellini, Aleqsander, dan Ns, t.t.) yang meneliti tentang pengaruh gel ekstrak daun kenikir (Cosmos caudatus H.B.K) terhadap penyembuhan luka eksisi tikus putih jantan (Rattus novergicus strain wistar) dan ekstrak daun kenikir sebagai repellent nyamuk (Hutagalung, Marsaulina, dan Naria 2013) bahwa ekstrak etanol daun kenikir dengan kosentrasi 15\% memiliki hasil yang paling baik juga, diduga ekstrak etanol daun kenikir 15\% merupakan konsentrasi optimum untuk penyembuhan luka.

\section{SIMPULAN DAN SARAN}

Berdasarkan hasil dan pembahasan maka dapat disimpulkan bahwa ekstrak etanol daun kenikir (Cosmos caudatus Kunth) $15 \%$ berpotensi sebagai obat penyembuh luka karena menunjukkan hasil yang lebih baik dari pengamatan mikroskopis dibandingkan dengan kontrol positif yang diolesi dengan povidone iodine, berdasarkan uji analisis ragam terhadap panjang luka dan waktu penyembuhan tidak adanya perbedaan yang nyata. Perlu dilakukan penelitian lebih lanjut dari ekstrak daun kenikir dengan menggunakan konsentrasi yang lebih tinggi dan dengan hewan uji yang berbeda.

Berdasarkan kesimpulan, dapat diajukan beberapa saran diharapkan dapat mengkaji masalah dengan jangkauan yang lebih luas dan selanjutnya dapat mencoba ekstrak lainnya. 
Ataupun penelitian ini dapat dijadikan referensi untuk penelitian selanjutnya.

\section{DAFTAR PUSTAKA}

Afianti, Hanum Pramuji, dan Mimiek Murrukmihadi. 2015. "Pengaruh Variasi Kadar Gelling Agent HPMC Terhadap Sifat Fisik dan Aktivitas Antibakteri Sediaan Gel Ekstrak Etanolik Daun Kemangi (Ocimum basilicum L. forma citratum Back.).” Majalah Farmaseutik 11 (2): 307-15.

Bontjura, Susriyani, Olivia Amelia Waworuntu, dan Krista Veronica Siagian. 2015. "Uji efek antibakteri ekstrak daun leilem ( Clerodendrum minahassae 1 .) terhadap bakteri streptococcus mutans" 4 (4).

Elnar, T V, dan T B Ailey. 2016. "The Wound Healing Process : an Overview of the Cellular and Molecular Mechanisms” 37 (5): 1528-42.

Homology, Genomic, Between Arabidopsis, Distantly Related, Plants Revealed, Comparative Genomic, dan Arabidopsis D N A Probe. 2007. "Dna 1) , 2) * 2) 430072)" 23 (39870423): 946-52.

Hutagalung, Dwisyahputra, Irnawati Marsaulina, dan Evi Naria. 2013. "Pengaruh Ekstrak Daun Kenikir (Tagetes Erecta L.) Sebagai Repellent Tehadap Nyamuk Aedes Spp.” Lingkungan dan Kesehatan Kerja 2 (2).

Izza, Ni'matul, Shinta Rosalia Dewi, Angky Wahyu Putranto, Dian R. Yuneri, dan Maria Yeniaska S. Dachi. 2016. "Extraction of Phenolic Compounds from Cosmos caudatus Using Pulse Electric Field (PEF).” Jurnal Teknologi Pertanian 17 (2): 91-96.

Kalangi, Sonny J R. 2013. "Histofisiologi kulit.” Jurnal Biomedik (JBM 3 (3): 12-20. https://doi.org/10.1016/j.jpedsurg.2016.11.019.

Kusumawardhani, Aliefia Ditha . Kalsum, Umi. Rini, Ika Setyo. 2015. "Effect of Betel Leaves Extract Oinment (Piper betle Linn.) on the Number of Fibroblast in IIA Degree Burn Wound on Rat (Rattus norvegicus) Wistar Strain." Majalah Kesehatan FKUB 2 (1): $16-28$.

Lodhi, Santram, dan Abhay K Singhai. 2013. "Wound healing effect of flavonoid rich fraction and luteolin isolated from Martynia annua Linn . on streptozotocin induced diabetic rats." Asian Pacific Journal of Tropical Medicine 6 (4): 253-59..

Massé, Maureen, Vincent Falanga, dan Linda Hua Zhou. 2008. "Use of topical povidone-iodine resulting in an iododerma-like eruption," no. July 2007: 744-47.

Murti, Dona Ayu, M Nur Salim, Mustafa Sabri, Studi Pendidikan, Dokter Hewan, Fakultas Kedokteran, Hewan Universitas, dkk. 2017. "1 , 2 , 3 1” 01 (3): 465-72. 
Napanggala, A, dan E Apriliana. t.t. "Effect of Jatropha's ( Jatropha curcas L . ) Sap Topically in The Level of Cuts Recovery on White Rats Sprague dawley Strain .

Orsted H, Keast D, Kuhnke J, Armstrong P, Attrell E, Beaumier M, ... Todoruk-Orchard. 2010. "Best Practice Recommendations for the Prevention and Management of Open Surgical Wounds." Wound Care Canada 8 (1): 6-34.

Rahim, Farida, Mimi Aria, dan Nurwani Purnama Aji. 2015. "Formulasi Krim Ekstrak Etanol Daun Ubi Jalar (Ipomoeae batatas L.) untuk Pengobatan Luka Bakar.” Scientia: Jurnal Farmasi dan Kesehatan 1 (1): 21-26.

Rahmatia, Tri Ulfa. 2016. "Proses Penyembuhan Luka Dan Perawatan Luka." Fakultas Farmasi, Universitas Padjajaran 4: 1-13.

Rahmawati, Ika. 2014. "Perbedaan efek perawatan luka menggunakan gerusan daun petai cina (Leucaena glauca, benth) dan povidon iodine 10\% dalam mempercepat penyembuhan luka bersih pada marmut (cavia porcellus)." Jurnal wiyata 1 (2): 227-34.

Rosellini, Monica, Mochammad Aleqsander, dan Thontowi Djauhari Ns. t.t. "Pengaruh Gel Ekstrak Daun Kenikir ( Cosmos caudatus H . B . K ) Terhadap Penyembuhan Luka Eksisi Tikus Putih Jantan ( Rattus novergicus strain.”

Teixeira, Silveira, Maria Antonia, Zancanaro De Figueiredo, Karen Cherubini, Maria Claudia, Rosa Garcia, Sílvia Dias, De Oliveira, dan Fernanda Gonçalves. 2018. "Archives of Oral Biology Topical chlorhexidine, povidone-iodine and erythromycin in the repair of traumatic ulcers on the rat tongue: Clinical, histological and microbiological evaluation." Archives of Oral Biology 87 (January): 218-25. https://doi.org/10.1016/j.archoralbio.2018.01.001. 
